\title{
Knowledge and adoption level of dairy farmers about bovine ectoparasites in the operational area of dairy Vigyan Kendra, Vejalpur, Gujarat (India)
}

\author{
SJ Jadav ${ }^{1}$, VD Chauhan ${ }^{2}$ and JJ Hasnani ${ }^{3}$
}

Received: 01 September 2020 / Accepted: 17 December 2020 / Published online: 07 June 2021

(C) Indian Dairy Association (India) 2021

\begin{abstract}
The study was carried out to assess the knowledge and adoption level of dairy farmers about bovine ectoparasites in the operational area of Dairy Vigyan Kendra (DVK), Vejalpur, Gujarat (India) during 2019-2020. Using the simple random sampling method, 300 respondents from 30 villages of 10 talukas in the operational area of Dairy Vigyan Kendra, Vejalpur were selected. Majority of dairy farmers $(80.33 \%)$ reported that their animals were suffering from ticks. An interview schedule was prepared encompassing various aspects of ectoparasites and their control to ascertain the level of knowledge. The majority of dairy farmers had medium level of knowledge $(42.33 \%)$ and adoption $(50.00 \%)$ about bovine ectoparasites. Dairy farmers can increase their knowledge about bovine ectoparasites through participation in various extension activities and use of different mass media which might reinforce them to adopt scientific practices regarding control of bovine ectoparasites.
\end{abstract}

Keywords: Adoption, Dairy farmers, Ectoparasite, Knowledge

\section{Introduction}

Ectoparasites are having economic significance on three points (1) direct losses from their bite and annoyance, worries, and psychological disturbances produced during the act of biting

${ }^{1}$ Dairy Vigyan Kendra, SMC College of Dairy Science, Anand Agricultural University, Anand-388110, Gujarat, India

${ }^{2}$ Department of Veterinary Parasitology, College of Veterinary Science and Animal Husbandry, Anand Agricultural University, Anand-388110, Gujarat, India

SJ Jadav( $\bowtie)$

Dairy Vigyan Kendra, SMC College of Dairy Science, Anand Agricultural University, Anand-388110, Gujarat, India

Email id: sanjay.jadav89@gmail.com and feeding, (2) diseases they transmit, and (3) expenditure incurred for their control (Narladkar, 2018). The global loss due to ticks and tick borne diseases (TTBDs) was estimated to be between US\$ 13.9 and 18.7 billion annually (De Castro, 1997) while in India the cost of controlling TTBDs has been estimated as US\$ 498.7 million/annum (Minjauw and McLeod, 2003).

The diseases spread by ticks are a major constraint to animal productivity while causing morbidity and mortality in both animals and humans. A number of tick species have been recognised since long as vectors of lethal pathogens, viz. Crimean-Congo haemorrhagic fever virus (CCHFV), Kyasanur forest disease virus (KFDV), Babesia spp, Theileria, Rickettsia conorii, Anaplasma marginale, etc. and the damages caused by them are wellrecognised (Ghosh and Nagar, 2014). Hence the knowledge and adoption by dairy farmers about ectoparasites and its control measures would help to make better planning for profitable dairy husbandry.

\section{Materials and Methods}

Study was conducted among the dairy farmers in operational area of Dairy Vigyan Kendra (DVK), Vejalpur. Eleven talukas are under operational jurisdiction of DVK. Out of eleven, seven talukas (Godhra, Shehera, Morva (Hadaf), Jambughoda, Ghoghamba, Halol, and Kalol) are under Panchmahals district and four talukas (Santrampur, Khanpur, Kadana and Lunawada) are under Mahisagar district. Total ten talukas of operational area of DVK were selected randomly for the study. Three villages were selected randomly from each taluka and 10 dairy farmers were selected randomly from each village, thus making the total sample of 300 dairy farmers. A standardized, well-structured pretested interview schedule was prepared in light of the objectives in consultation with department of veterinary parasitology and veterinary experts. The data were collected through personal interview method. Knowledge score card was developed by assigning one score to each correct response and zero score to each incorrect response. The score of " 2 " was assigned to those respondents who adopt the particular practice fully. The partial adoption of practice was given " 1 " score while " 0 " score was given to those respondents who do not adopt the particular practice. Adoption is a decision to make full use of an innovation 
as the best course of action available. If the practice adopted was fairly close to the recommendation, it was viewed as partially adopted. Partial adoption is common, at least for some practices. Respondents were categorized into low, medium, and high categories for knowledge level, adoption level, milk production, social participation, extension participation and mass media exposure variables with help of cumulative square root of frequency (CSRF) method suggested by Dalenius and Hodges (1959). SPSS 21 (IBM, USA) was used to process the collected data.

\section{Results and Discussion}

The complete profile of dairy farmers comprising of different personal and socio-economical characteristics is depicted in Table 1. In the study area, more than half of the dairy farmers were female (58.33), middle aged group (50.66\%), and literate (65.00\%). Similar result was reported by Jadav and Raval (2019). Vast majority of dairy farmers $(92.34 \%)$ had kept buffalo followed by crossbred cow (50.00\%) and indigenous cow (22.00\%). Results indicated that dairy farmers $(45.67 \%)$ had kept two milch animals in their dairy farm followed by one or no milch animal $(38.33 \%)$ and three or more than three milch animals (16.00\%). There were 45.00 per cent dairy farmers' animals, which produced less than 9 litres of milk per day. Majority of dairy farmers had medium level of social participation (56.00\%), extension participation $(42.33 \%)$ and mass media exposure $(43.67 \%)$. The probable reason could be that majority of dairy farmers had registered in milk cooperative society to get the benefit of AMUL pattern having strong network of animal husbandry services like veterinary service, extension activities etc.

Table 1 Profile of dairy farmers

$(\mathrm{n}=300)$

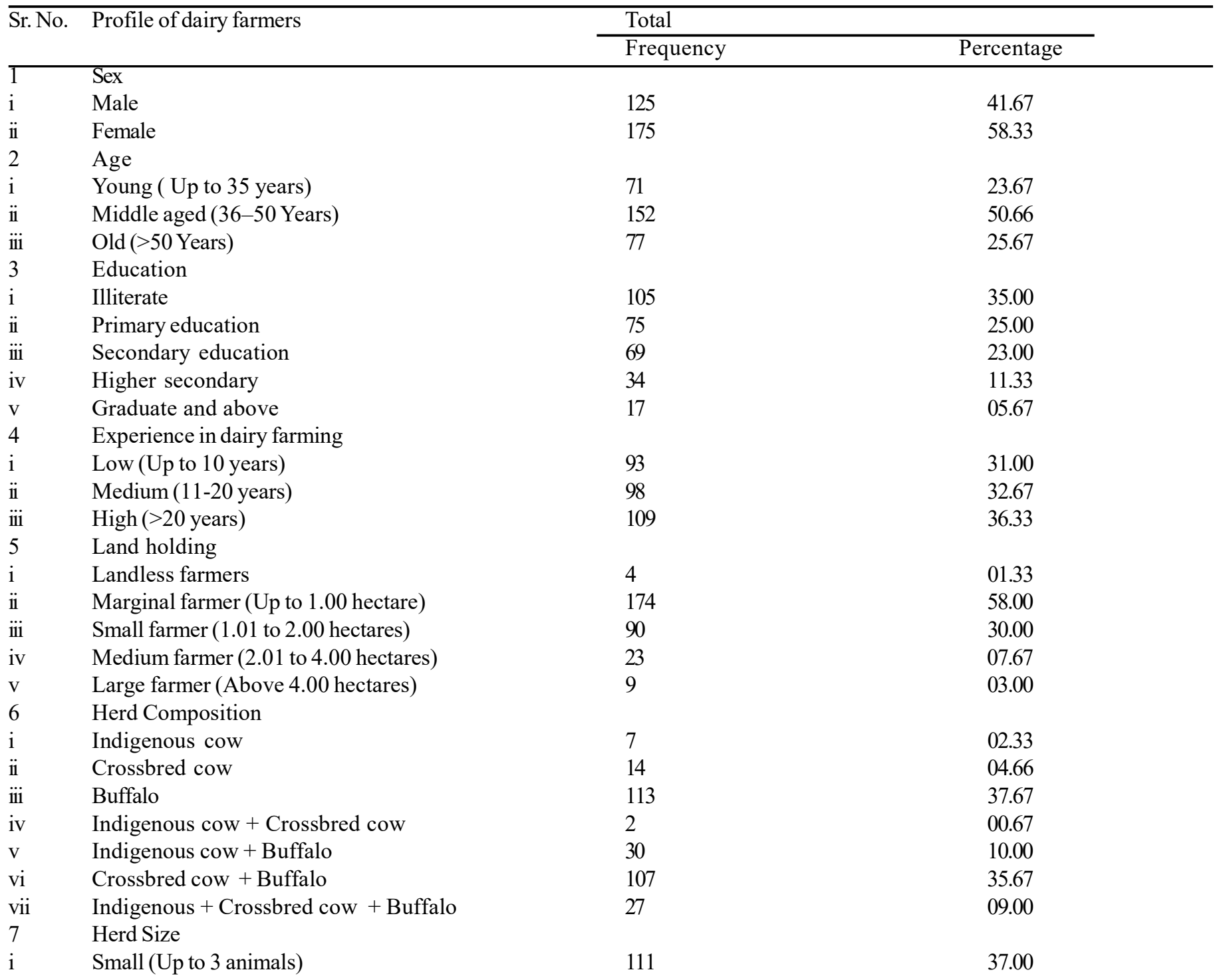




\begin{tabular}{|c|c|c|c|}
\hline ii & Medium (4-6 animals) & 112 & 37.33 \\
\hline iii & Large ( $>6$ animals) & 77 & 25.67 \\
\hline 8 & Milch animal & & \\
\hline $\mathrm{i}$ & Low (d"1 milch animal) & 115 & 38.33 \\
\hline iii & High (e"3 milch animals) & 48 & 16.00 \\
\hline 9 & Milk Production/ Day/ Farmer & & \\
\hline iii & High ( $>21$ litres $)$ & 55 & 18.33 \\
\hline 10 & Social participation & & \\
\hline $\mathrm{i}$ & Low $(<0.41)$ & 78 & 26.00 \\
\hline ii & Medium(0.41-2.09) & 168 & 56.00 \\
\hline iii & $\operatorname{High}(>2.09)$ & 54 & 18.00 \\
\hline iii & $\operatorname{High}(>4.24)$ & 73 & 24.34 \\
\hline 12 & Mass media exposure & & \\
\hline $\mathrm{i}$ & Low $(<0.59)$ & 104 & 34.67 \\
\hline ii & Medium (0.59-2.11) & 131 & 43.67 \\
\hline iii & $\operatorname{High}(>2.11)$ & 65 & 21.66 \\
\hline
\end{tabular}

(-) indicate the wrong question asked to respondents.

Two-fifth dairy farmers $(39.67 \%)$ had knowledge about the difference between endoparasite and ectoparasite in operational area of DVK (Table 2). There were 92.00 per cent dairy farmers who had knowledge that ticks coming under ectoparasite followed by flies $(84.00 \%)$, lice $(76.33 \%)$, mosquito $(70.33 \%)$ and mites/ mange $(63.67 \%)$. There were 98.00 per cent of dairy farmers who knew that ectoparasite can be susceptible to buffalo followed by cow $(94.67 \%), \operatorname{dog} \&$ cat $(48.00 \%)$, sheep \& goat $(32.00 \%)$, horse $(19.67 \%)$ and camel $(16.00 \%)$.

Regarding the transmission of bovine ectoparasite, 68.00 per cent of dairy farmers believed that bovine ectoparasite infestation can be transmitted to human. Majority of dairy farmers (83.67\%) believed that ectoparasite infestation can be transmitted from animal to animal. It is seen in the table 2 that more than one-third $(37.67 \%)$ of dairy farmers had knowledge that ingestion of contaminated milk is unable to transmit ectoparasite infestation to human and vice versa. Dairy farmer had knowledge about ectoparasite infestation of animals can be transmitted through bite of arthropods ( $71.00 \%)$ and contact of infected animal's skin $(64.67 \%)$ to human and vice versa.

When asked about symptoms of animal suffering from ectoparasites infestation, majority of dairy farmers $(91.33 \%)$ had knowledge that it causes harm to animals by biting and blood sucking followed by intense skin irritation, marked itching and scratching $(91.00 \%)$, septicemia or toxaemia $(67.00 \%)$ and myiasis $(56.00 \%)$.
Regarding various diseases transmitted due to ectoparasites, dairy farmers had knowledge that ectoparasite infestation can mechanically transmit tuberculosis (31.33\%), typhoid (24.67\%), anthrax $(21.00 \%)$, cholera $(12.33 \%)$ and crimean-congo haemorrhagic fever (CCHF) (11.67\%). There was less than half $(47.00 \%)$ dairy farmers, who had the knowledge that ectoparasites can transmit trypanosomiasis followed by theileriosis (34.33\%) and babesiosis (11.67\%). Manimaran and Kamboj (2014) reported that ectoparasites infestation reduced animal production and performance, partly through transmission of arthropod-borne diseases like trypanosomiasis, babesiosis and theileriosis.

Majority of dairy farmers believed that treatment of infested animal by a veterinarian can prevent ectoparasites $(92.67 \%)$, usage of home remedies like neem oils $(59.00 \%)$, use of insects preventive net $(51.67 \%)$, use of $\mathrm{CaCO} 3$ (Calcium carbonate) to control ectoparasites in the animal shed soil $(35.00 \%)$ and regular bathing of animal $(96.00 \%)$ followed by various pour-on insecticides or acaricides, which should be used under the guidance of a veterinary doctor $(85.33 \%)$ and maintain proper distance between the animals to be kept to avoid the transfer of ectoparasites from one animal to another $(73.33 \%)$.

Majority of dairy farmers' animals were suffering from ticks, which indicates that tick is a burning question in dairy farming (Table 3). Similar result was revealed by Ramzan et al. (2018) and reported that most interviewees $(78.30 \%)$ knew well that their animals had ticks. 
Table 2 Knowledge of dairy farmers about bovine ectoparasites $\quad(n=300)$

\begin{tabular}{|c|c|c|}
\hline$\overline{\text { Sr.No }}$ & Statements & No. $(\%)$ of \\
\hline & General Information & participants \\
\hline 1 & $\begin{array}{l}\text { Number of respondents knowing the difference between } \\
\text { endoparasite and ectoparasites }\end{array}$ & $119(39.67)$ \\
\hline 2 & $\begin{array}{l}\text { Number of respondents who know different types of ectoparasites in } \\
\text { dairy animals }\end{array}$ & \\
\hline A & Ticks & $276(92.00)$ \\
\hline B & Mites / Mange & $191(63.67)$ \\
\hline $\mathrm{C}$ & Lice & $229(76.33)$ \\
\hline $\mathrm{D}$ & Flies & $252(84.00)$ \\
\hline $\mathrm{E}$ & Mosquito & $211(70.33)$ \\
\hline $\mathrm{F}$ & Dragonflies (-) & $155(51.67)$ \\
\hline G & Grasshopper (-) & $158(52.67)$ \\
\hline 3 & Susceptible animals that can have ectoparasites & \\
\hline A & Cow & $284(94.67)$ \\
\hline B & Buffalo & $294(98.00)$ \\
\hline $\mathrm{C}$ & Dog \& Cat & $144(48.00)$ \\
\hline $\mathrm{D}$ & Sheep \& Goat & $96(32.00)$ \\
\hline $\mathrm{E}$ & Horse & $59(19.67)$ \\
\hline $\mathrm{F}$ & Camel & $48(16.00)$ \\
\hline 4 & Ectoparasite infestation as a curable condition & $230(76.67)$ \\
\hline 5 & $\begin{array}{l}\text { Ectoparasite infestation as treatable } \\
\text { Transmission }\end{array}$ & $254(84.67)$ \\
\hline 6 & Bovine ectoparasite infestation can be transmitted to farmers. & $204(68.00)$ \\
\hline 7 & Ectoparasite infestation can be transmitted from animal to animal. & $251(83.67)$ \\
\hline 8 & $\begin{array}{l}\text { Ectoparasite infestation of animals can transmit to man and vice } \\
\text { versa through: }\end{array}$ & \\
\hline A & Ingestion of contaminated milk (-) & $113(37.67)$ \\
\hline B & Contact of infected animal's skin & $194(64.67)$ \\
\hline $\mathrm{C}$ & $\begin{array}{l}\text { Bite of arthropods } \\
\text { Symptoms of animal (Suffering from Ectoparasite infestation) }\end{array}$ & $213(71.00)$ \\
\hline 9 & $\begin{array}{l}\text { Ectoparasite infestation causes intense skin irritation, marked itching } \\
\text { and scratching }\end{array}$ & $273(91.00)$ \\
\hline 10 & Ectoparasite infestation causes myiasis & $168(56.00)$ \\
\hline 11 & Ectoparasite cause septicemia or toxaemia & $201(67.00)$ \\
\hline 12 & $\begin{array}{l}\text { Ectoparasite causes harm to animals by biting and blood sucking } \\
\text { Various diseases transmitted due to ectoparasites }\end{array}$ & $274(91.33)$ \\
\hline 13 & $\begin{array}{l}\text { Ectoparasite infestation mechanically transmit viral and bacterial } \\
\text { diseases like: }\end{array}$ & \\
\hline A & Crimean-Congo haemorrhagic fever (CCHF) & $35(11.67)$ \\
\hline B & Typhoid & $74(24.67)$ \\
\hline $\mathrm{C}$ & Anthrax & $63(21.00)$ \\
\hline $\mathrm{D}$ & Cholera & $37(12.33)$ \\
\hline $\mathrm{E}$ & Tuberculosis & $94(31.33)$ \\
\hline 14 & $\begin{array}{l}\text { Ectoparasite transmit certain protozoal and rickettsial organisms } \\
\text { which causes diseases like: }\end{array}$ & \\
\hline A & Trypanosomosis & $141(47.00)$ \\
\hline B & Theileriosis & $103(34.33)$ \\
\hline $\mathrm{C}$ & $\begin{array}{l}\text { Babesiosis } \\
\text { Prevention \& Control of ectoparasite infestation }\end{array}$ & $35(11.67)$ \\
\hline 15 & Treatment of infested animal by a veterinarian & $278(92.67)$ \\
\hline 16 & Usage of home remedies like neem oils to prevent ectoparasite effective & $177(59.00)$ \\
\hline
\end{tabular}




$\begin{array}{lll}17 & \text { Insects preventive net can control ectoparasites } & 155(51.67) \\ 18 & \text { CaCO3 (Calcium carbonate) can be useful to control ectoparasites in } \\ \text { the animal shed soil. } & 105(35.00) \\ 19 & \begin{array}{l}\text { To use various pour-on insecticides or acaricides under the guidance } \\ \text { of a veterinary doctor }\end{array} & 256(85.33) \\ 20 & \begin{array}{l}\text { Regular bathing of animal is advisable for control of ectoparasites. } \\ \text { To maintain proper distance between the animals for avoid } \\ \text { the transfer of ectoparasites from one animal to another }\end{array} & 288(96.00) \\ & \end{array}$

Table 3 Dairy farmers' response regarding presence of ticks on their dairy animals $\quad(n=300)$

\begin{tabular}{lllc}
\hline Sr. No. & Presence of ticks & Frequency & Percentage \\
\hline i & Yes & 241 & 80.33 \\
ii & No & 59 & 19.67 \\
\hline
\end{tabular}

Table 4 Knowledge level of dairy farmers about major components of bovine ectoparasites $\quad(n=300)$

\begin{tabular}{llc}
\hline Sr.No. & Major components & Knowledge level (\%) \\
\hline 1 & General information & 62.08 \\
2 & Transmission & 64.33 \\
3 & Symptoms of animal & 76.33 \\
4 & Various diseases transmitted due to ectoparasites & 21.56 \\
5 & Prevention \& Control of ectoparasite infestation & 70.43 \\
\hline
\end{tabular}

Knowledge level of dairy farmers about major components of bovine ectoparasites (Table 4) revealed that an arrangement of major components of dairy farmers' knowledge level about bovine ectoparasites as 'Symptoms of animal Prevention and Control of Ectoparasite infestation, Transmission, General information, Various diseases transmitted due to ectoparasites' are ordered in decreasing trend. Dairy farmers had least knowledge level (21.56\%) about various diseases transmitted due to ectoparasites. This result indicates that extension programmes should put more emphasis on various diseases transmitted due to ectoparasites. Similar result was found by Sarita et al. (2017) and reported that only 42.8 per cent of respondents knew only two harms adverse effects followed by $<2$ harms $(36.4 \%)$ and $>2$ harms of ectoparasites $(20.8 \%)$. There is need of extension programmes to educate the farmers about diseases transmitted through ectoparasites and to reduce the economic loss to the farmers (Ponnusamy et al. 2017).

It is observed in table 5 that majority of dairy farmers (42.33\%) had medium level of knowledge about bovine ectoparasites followed by 33.00 and 24.67 per cent of them had high and low level of knowledge of bovine ectoparasites, respectively. Knowledge of herdsmen was not good about ticks and tickborne diseases in district Multan reported by Ramzan et al. (2018). There was 50.00 per cent dairy farmers had medium adoption of practices regarding control of bovine ectoparasites followed by high adoption (26.67\%) and low adoption (23.33\%). These findings were not in agreement with results of Ramzan et al. (2018), Kumar (2015) and Yadav et al. (2009) and reported that majority of respondents did not follow any practice to control ecto-parasites.
Adoption of dairy farmers regarding practices associate to control bovine ectoparasites presented in table 6 . More than half of dairy farmers $(55.00 \%)$ had not adopted the practice of treatment of infected animal by a veterinarian. It was found that more than fifty per cent dairy farmers had partially adopted the practice of maintaining the proper distance between the animals to avoid the transfer of ectoparasites from one animal to another (59.33\%). Majority of dairy farmers (93.33\%) had not adopted insects preventive net followed by calcium carbonate $(83.67 \%)$ and home remedies like neem oils (62.67\%) to prevent \& control of bovine ectoparasites (Ponnusamy et al. 2017). More than half (54.33\%) of dairy farmers had fully adopted the practice of regular bathing of animals for effective control of ectoparasite. These findings were in agreement with results of Singh (2018) and Malsawmdawngliana and Rahman (2016) and reported that majority of the respondents did nothing to control ectoparasites in animal house

The Pearson correlation analysis was conducted to identify the relationship between factors affecting the knowledge level of dairy farmers about bovine ectoparasite and independent variables. An observation of table 7 shows that ' $r$ ' computed between knowledge level of dairy farmers about bovine ectoparasite and mass media exposure $(0.240)$, extension participation (0.234), education (0.226), landholding $(0.218)$ and herd size $(0.158)$ were found to be significant at 0.01 level of significance. Social participation (0.137) and milk production (0.134) were found to be significant at 5 per cent. Remaining variables like age and experience in dairy farming were observed to be non-significant relationship. The result shows that the 
Table 5 Overall knowledge and adoption level of dairy farmers about bovine ectoparasites $(n=300)$

\begin{tabular}{llllc}
\hline Sr.No. & Knowledge category & $\begin{array}{l}\text { Knowledge } \\
\text { categoryNo. }(\%)\end{array}$ & Adoption category & $\begin{array}{c}\text { Adoption } \\
\text { categoryNo. }(\%)\end{array}$ \\
\hline 1 & Low $(<19.44)$ & $74(24.67 \%)$ & Low $(<2.84)$ & $70(23.33)$ \\
2 & Medium $(19.44-25.88)$ & $127(42.33)$ & Medium $(2.84-5.29)$ & $150(50.00)$ \\
3 & High $(>25.88)$ & $99(33.00)$ & High $(>5.29)$ & $80(26.67)$ \\
\hline
\end{tabular}

Table 6 Adoption of dairy farmer regarding practices in control of bovine ectoparasites $\quad(n=300)$

\begin{tabular}{llllc}
\hline Sr.No. Practices & \multicolumn{2}{c}{ No. (\%) of participants } \\
\cline { 3 - 5 } & & Full adoption & Partial adoption & No adoption \\
\hline 1 & $\begin{array}{l}\text { Treatment of infested animal by a veterinarian } \\
\text { Usage of home remedies like neem oils to }\end{array}$ & $\begin{array}{l}135(45.00) \\
\text { prevent ectoparasite effective }\end{array}$ & $0(00.00)$ & $165(55.00)$ \\
3 & $\begin{array}{l}\text { Use of insects preventive net to control } \\
\text { ectoparasites }\end{array}$ & $20(06.67)$ & $0(00.00)$ & $280(93.33)$ \\
4 & $\begin{array}{l}\text { Use of CaCO3 (Calcium carbonate) to control } \\
\text { ectoparasites in the animal shed soil }\end{array}$ & $18(06.00)$ & $31(10.33)$ & $251(83.67)$ \\
5 & $\begin{array}{l}\text { Regular bathing of animals for effective } \\
\text { control of ectoparasite }\end{array}$ & $163(54.33)$ & $132(44.00)$ & $5(01.67)$ \\
6 & $\begin{array}{l}\text { Maintaining the proper distance between the } \\
\text { animals to avoid the transfer of ectoparasites } \\
\text { from one animal to another }\end{array}$ & $77(25.67)$ & $178(59.33)$ & $45(15.00)$ \\
\hline
\end{tabular}

Table 7 Correlation (r) between the profile of dairy farmers with knowledge and adoption of dairy farmer about bovine ectoparasite $(\mathrm{n}=300)$

\begin{tabular}{lllc}
\hline Sr.No. & Variables & $\begin{array}{l}\text { Pearson 'r' value } \\
\text { (Knowledge) }\end{array}$ & $\begin{array}{c}\text { Pearson 'r' value } \\
\text { (Adoption) }\end{array}$ \\
\hline 1 & Age & $0.006^{\mathrm{NS}}$ & $-0.065^{\mathrm{NS}}$ \\
2 & Education & $0.226^{* *}$ & $0.151^{* *}$ \\
3 & Experience in dairy farming & $0.088^{\mathrm{NS}}$ & $-0.070^{\mathrm{NS}}$ \\
4 & Landholding & $0.218^{* *}$ & $0.162^{* *}$ \\
5 & Herd size & $0.158^{* *}$ & $-0.050^{\mathrm{NS}}$ \\
6 & Milk production & $0.134^{*}$ & $0.021^{\mathrm{NS}}$ \\
7 & Social participation & $0.137^{*}$ & $-0.040^{\mathrm{NS}}$ \\
8 & Extension participation & $0.234^{* *}$ & $0.106^{\mathrm{NS}}$ \\
9 & Mass media exposure & $0.240^{* *}$ & $0.235^{* *}$ \\
10 & Knowledge of dairy farmers & - & $0.347^{* *}$ \\
\hline
\end{tabular}

** =Significant at 0.01 level; * =significant at 0.05 level; NS= non-significant

knowledge level about bovine ectoparasites was significantly increasing with increase in exposure to mass media, participation in extension \& social activities, educational level and socioeconomic condition of dairy farmer (Ponnusamy et al. 2019).

An observation shows that correlation ' $r$ ' computed between adoption of dairy farmer about practices of control of bovine ectoparasites and education (0.151), landholding $(0.162)$ and mass media exposure $(0.235)$ were found to be significant at 1 per cent.

The result shows that the adoption level of dairy farmer about practices of control of bovine ectoparasites had significant increase with increasing their mass media exposure, landholding and educational level. Mass media exposure might have enhanced the awareness of dairy farmers on different practices of bovine ectoparasites' control. Education of dairy farmer might be useful to understand the advantages of different practices of bovine ectoparasites' control. Landholding represents the economic condition of dairy farmer which may be helpful to bear the extra expenses of adopted practices for controlling bovine ectoparasites.

Correlation between knowledge level and adoption level of dairy farmer (0.347) regarding bovine ectoparasites was found to be significance at 1 per cent. It signifies that adoption level of dairy 
farmer about control of bovine ectoparasites would increase with his knowledge level.

\section{Conclusion}

The survey of dairy farmers in Panchmahals and Mahisagar districts of Gujarat indicated that farmers are aware of impact of tick infestation in dairy animals. However, the adoption of control measures was found to be medium, requiring extension interventions. The correlation between 'Knowledge level and adoption level of dairy farmer about control of bovine ectoparasites' with education, landholding and mass media exposure was found to be highly significant.

Ectoparasite control programmes (especially focus on tick control programmes) should be organized by maximum mass media exposure as well as level by providing trainings, awareness programmes and literatures on bovine ectoparasite to the dairy farmers.

\section{References}

Dalenius T, Hodges J L (1959) Minimum variance stratification. J Am Stat Assoc 54: 88-101

De Castro JJ (1997) Sustainable tick and tick-borne disease control in livestock improvement in developing countries. Vet Parasitol 71: 77-79

Ghosh S, Nagar G (2014) Problem of ticks and tick-borne diseases in India with special emphasis on progress in tick control research: A review. $\mathrm{J}$ Vector Borne Dis 51: 259-270

Jadav S J, Raval S K (2019) Consciousness of Dairy Farmers about Brucellosis. Int J Curr Microbiol App Sci 8: 1404-1415
Kumar M (2015) Buffalo healthcare management practices followed by the farmers of Ferozepur district of Punjab. India. Indian J Anim Res 49:413-415

Malsawmdawngliana R, Rahman S (2016) Management practices followed by the dairy farmers of Mizoram, India. J Livest Sci 7: 220-225

Manimaran A, Kamboj M L (2014) National code of practice for management of dairy animals in India. ICAR- National Dairy Research Institute, Karnal, pp 53-54

Minjauw B, McLeod A (2003) Tick-borne diseases and poverty: The impact of ticks and tick-borne diseases on the livelihood of small scale and marginal livestock owners in India and eastern and southern Africa. Research Report, DFID-AHP. UK: Centre for Tropical Veterinary Medicine, University of Edinburgh, pp 116

Narladkar BW (2018) Projected economic losses due to vector and vectorborne parasitic diseases in livestock of India and its significance in implementing the concept of integrated practices for vector management. Vet World 11: 151-160

Ponnusamy K, Chakravarty R, Singh, Sohanvir (2019) Extension interventions in coping of farmers against effect of climate change in dairy farming. Indian J Dairy Sci 72: 430-436

Ponnusamy K, Kale R B, Ravi K N, Arulmozhi Devi M C, Sharma P (2017) Cross-regional analysis on usage of Indigenous Technical Knowledge in dairy farming. Indian J Anim Res 51: 549-556

Ramzan M, Unsar N U, Syed H M B, Ghulam M, Alamgir A K (2018) Knowledge, attitude and practices of herdsmen about ticks and tick -borne diseases in district Multan. Pak Entomol 40: 13-18

Sarita, Singh S P, Sangwan S S, Rachna, Ahuja R (2017) Knowledge of Dairy Farmers Regarding Improved Buffalo Health Care Practices in Murrah Tract of Haryana State. Int J Pure App Biosci 5: 13161321

Singh R (2018) Existing Animal Husbandry Practices in Narmada District of Gujarat in India. Int J Anim Sci Technol 2: 23-29

Yadav C M, Bhimawat B S, Khan P M (2009) Existing breeding and healthcare practices of cattle in tribals of Dungarpur district of Rajasthan. Indian Res J Ext Edu 9: 36-38 